\title{
研究室紹介
}

\section{北里大学海洋生命科学部 増殖生物学講座 魚類分子内分泌学研究室}

水澤 寛太 (北里大学 海洋生命科学部)

E-mail: mizusawa@kitasato-u.ac.jp

\section{研究室について}

当研究室は高橋明義教授と准教授の水澤の教員 2 名と 4名の研究員、そして13名の学部4年生で構成されて います。大学院生は毎年少なくて今年はゼロです。4年 生の活動は朝 9 時半から夕方 17 時までがコアタイムと なっています。9時半からは研究室全体でブリーフィン グを行ない、当日の全員の予定をお互いに確認し合いま す。就職活動があるので学部生が全員揃うことはほとん どありません。欠席や遅刻の連絡には LINE を使ってい ます。当初は使い方がよくわからず学生に教わったので すが、「お母さんみたいだ」と笑われました。

学生は研究進捗報告のためにセミナーで発表します。 学生 1 人あたり発表の機会は月に $1 、 2$ 回程度ですが、 人数が多いためセミナーは頻繁に開かれます。高橋教授 日く「血祭り」ということで、教員と研究員総がかりで 優しく指導し可愛がります。そして最後、2月の中旬頃 に卒業論文発表会を行ないます。この発表会は、天野勝 文先生々阿見彌典子先生の主催する水族生理学研究室と の合同で、学生が最も緊張する行事です。ここでお互い に初めて知るデータもあって、とても刺激になります。 同じ手法を使っている発表や、テーマが共通する発表で は、学生間で鋭い質問が飛びます。本質的な質問が出る こともあって、学生の成長を最も感じる瞬間です。

\section{研究テーマについて}

私たちの研究室は、脳と下垂体のホルモンの機能に着 目しつつ、環境の光波長と魚類の生理との関係を探って います。メラニン凝集ホルモン $(\mathrm{MCH})$ は、哺乳類の 視床下部の食欲中枢において食欲克進にはたらくホルモ ンですが、魚類においては環境の明るさに応じて血中に 分泌され、その名のとおり黒色素や黄色素を凝集して 体色を明化します。高橋教授と岩手県水産技術センター との共同研究によって、白い水槽の中でカレイ (マツカ ワ）を飼育すると $\mathrm{MCH}$ の産生・分泌が亢進し、体色が 明化すると同時に成長が速くなることが明らかになりま した。また、マツカワに緑色光を照射すると成長が速く なることも明らかになりました。2016年3月に、体色 調節ホルモンの基礎研究が水産業の発展に貢献したとし て高橋教授に日本水産学会進歩賞が授与されました。そ の後、国立研究開発法人水産研究・教育機構、神奈川県 水産技術センター、LED メーカーのスタンレー電気株 式会社等との共同研究が進み、ヒラメ、ホシガレイ、マ コガレイにおいても緑色光に成長促進効果があることが わかりました。しかし、なぜ緑色光がカレイ類の成長を 促進するのか、その内分泌メカニズムは未だに明らかに

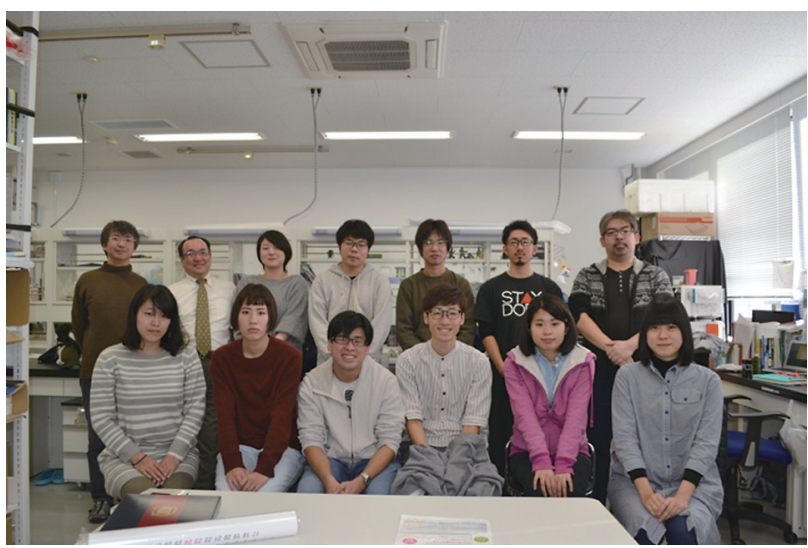

研究室メンバー(後列左端が筆者、右隣が高橋教授)

なっていません。 $\mathrm{MCH}$ 遺伝子の発現は、緑色光照射に よってしばしば充進しますが、低水温では克進しないこ ともあります。しかし、調べたどの水温においても緑色 光照射は成長を促進します。したがって、緑色光の成長 促進効果は $\mathrm{MCH}$ のはたらきだけでは説明できません。 現在、私たちは色覚、摂食調節、代謝調節など、カレイ の生理機能を多面的に解析してこの謎に挑んでいます。

ここで、水澤の研究テーマの一つである観賞魚の体色 調節機構について紹介します。キンギョやニシキゴイは 体色の模様や鮮やかさを指標に品種改良されてきまし た。魚類では、黒色素胞や黄色素胞において色素顆粒が 拡散すると、体色が濃く鮮やかになります。したがって、 品種改良されたキンギョやニシキゴイでは、色素顆粒が 拡散するような何らかの変異が蓄積していると考えられ ます。ニシキゴイを白い水槽で飼育したところ、黒い水 槽で飼育したときに比べて体色が白くなりました。しか し、このとき黒色素胞の色素顆粒は完全には凝集しませ んでした。さらに MCHに着目して解析を進めたところ、 ニシキゴイではマゴイに比べて脳内の $\mathrm{MCH}$ 遺伝子発 現レベルが低く、さらに色素胞に対する $\mathrm{MCH}$ の色素 凝集活性が極めて低いことがわかりました。ニシキゴ イ（を鑑賞する人間）にとって、MCH は体色を薄くし てしまう邪魔なホルモンであるといえます。おそらく品 種改良の過程において MCH の発現とその作用が減弱 するような遺伝的変異が蓄積されたのでしょう。しかし ながら、興味深いことにニシキゴイに $\mathrm{MCH}$ を腹腔内 注射すると色素顆粒はほぼ完全に凝集します。どうやら $\mathrm{MCH}$ の生理作用のすべてが消失したわけではないよう です。私は、ニシキゴイを $\mathrm{MCH}$ 機能の変異体とみな して研究を進めることによって、MCH の隠れた生理作 用を明らかにできるのではないかと考えています。 
最後になりますが、研究室紹介の機会を与えていただ きました天野勝文先生にこの場を借りて御礼申し上げま す。前号 (2017年9月号) に阿見彌先生による水族生理
学研究室の紹介が掲載されています。相模原にお越しの 際は、水族生理学研究室だけでなく魚類内分泌学研究室 にも気軽にお立ち寄りください。

\section{National Institutes of Health (NIH), Yun-Bo Shi 研究室}

谷崎 祐太 (NICHD, National Institutes of Health) E-mail: yuta.tanizaki@nih.gov

筆者は昨年度まで早稲田大学、加藤尚志研究室で力 エルモデルによる造血制御系を研究していましたが、4 月よりアメリカ国立衛生研究所 (National Institutes of Health) の Yun-Bo Shi *研究室に留学し、器官発達に関 わる甲状腺ホルモン制御系、特に甲状腺ホルモン受容体、 p300について研究しています。

\section{National Institutes of Health と NICHD}

$\mathrm{NIH}$ はアメリカ合衆国の東海岸、メリーランド州南 端のベセスダ（首都ワシントン DC から北に $4 \mathrm{~km}$ 程の 場所）に位置する 1887 年に設立された医学研究機関で す。NIH はアメリカ合衆国保健福祉省に属する医学研 究機関であるだけではなく国の研究費も分配しており、 これまでに支援をうけた 150 人以上の研究者がノーベル 賞を受賞しています。NIH は27の機関で構成されて おり、その中には私達に馴染夕の深い PubMed や Blast を運営する National Library of Medicineも含まれてい ます。私はその中の National Institutes of Child Health and Human Development (NICHD) に所属しておりま す。NICHD は 1962 年に「受精から老いへの人間発生 の複雑なプロセス」を研究するためにジョン F. ケネディ 大統領により設立された機関です。NICHD 内はさら に13のグループに分かれており、Cell Regulation and Development (CRD) グループ 内に属する一つの研究室 が Yun-Bo Shi 研究室です。年に2回 NICHD の研究交 流会がある他、CRDのポスドクは持ち回りで毎週水曜 日のランチタイムに 1 時間セミナーを行います。本セミ ナーには全 PI が参加し、研究成果についてだけではな く研究の方向性から、キャリアに至るまで議論されま す。このように研究機関のイメージが強いNIHですが、 ポスドクが学ぶ上で非常に恵まれた環境が整っておりま す。

\section{研究室について}

Yun-Bo 研究室では主にツメガエル (X. tropicalis, X. laevis）をモデル動物として器官発達における甲状腺ホル モン (TH)、甲状腺ホルモン受容体 (TR) 機能および分 子機構を研究しています。ツメガエルのオタマジャクシ はTHにより変態が誘導されると、幼生型の臓器から 成体型へと臓器が再構築されます。中でも幹細胞分裂の 盛んな小腸は、構造および機能が春椎動物間で高度に保 存されているため、モデル動物による幹細胞を研究する

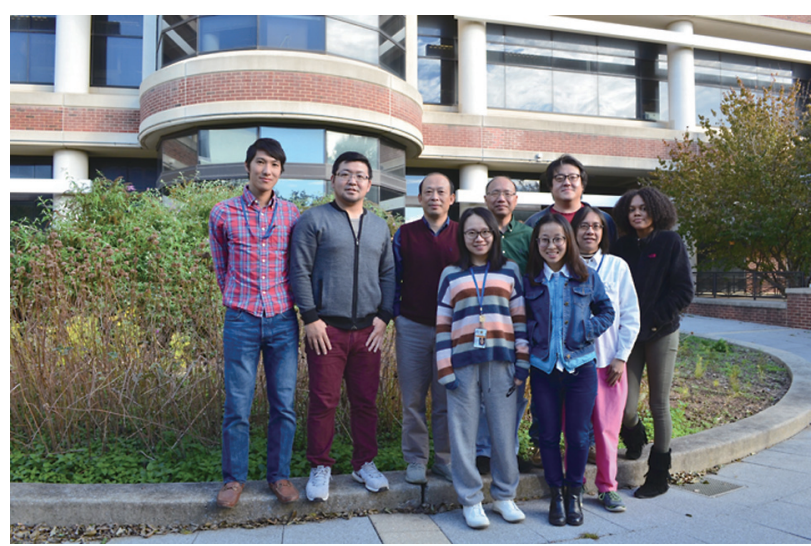

研究室メンバーの集合写真

筆者 (左端)、比較内分泌学会会員の柴田侑毅博士 (筆者隣) と共に。Dr. Yun-Bo Shi は左から3番目。

際の優れた臟器の一つだと考えられます。我々はこれ まで、 $\mathrm{TH}$ による幼生小腸上皮細胞の脱分化を介して成 体小腸上皮幹細胞が誘導されること、 $\mathrm{TH}$ が変態期にお いて小腸上皮幹細胞ニッチに作用することを報告してき ました。分子機構に着目すると、TH は核に進入すると TR と結合し、受容体複合体を形成することにより甲状 腺ホルモン応答遺伝子を活性化します。THと TRの発 現時期は必ずしも一致しませんが、これまでの研究にお いて、リガンド非結合型 TR は、コリプレッサーである N-CoR、SMRT、HDAC 等と複合体を形成することを 明らかにしました。さらに、TH 刺激によりリガンド結 合型 TRとなるとコリプレッサーが外れ、コアクチベー ターである SRC3、p300、DRIP/TRAP がリクルートさ れることが分かりました。本成果より、発生時において 器官再構築の準備が整うまでは、動物の成長を促すため に器官再構築のスイッチをオフにしておき、TH が誘導 された時点でオンとなるように臓器再構築の時期を調整 していると考えられるようになりました。しかし、組 織幹細胞に与える個々の機能については未解明な点が多 く残されており、我々は現在、変態期における組織幹細 胞およびニッチの分子変化に着目して研究を進めており ます。

研究室には現在リサーチサイエンティスト 1 名、テク ニシャン 1 名、ポスドク研究員 3 名、ポスバク 1 名、学 生 2 名の計 9 人のラボです。アメリカの研究室ではあり ますが、在籍するメンバーの国籍はアメリカの他に中 